\title{
Dying and Restoration in Oscar Wild's The Importance of Being Earnest and Wole Soyinka's The Lion And The Jewel
}

\author{
Amechi Nicholas Akwanya, Emeka Thomas Michael Chukwumezie \\ Department of English and Literary Studies University of Nigeria, Nsukka \\ Department of English and Literary Studies University of Nigeria, Nsukka
}

\begin{abstract}
Oscar Wilde's The Importance of Being Earnest and Wole Soyinka's The Lion and the Jewel are plays often read for their social relevance, rarely picking up their classical resonance and discovering their deeper levels of meaning. As a result, discussions tend to focus on what might be the point of the play. In this paper in which we follow Northrop Frye in exploring comedy to its roots in myth and ritual, we shall examine the deep mythic forms that underlie the two plays. This enables us to see them as sequences re-enacting the spring archetype in which life and community are renewed and rejuvenated.
\end{abstract}

Keywords: archetype, comedy, enactment, fruitfulness, myth, mythical form, representation, ritual, sequence, spring, vegetation cycle

\section{Introduction}

Overwhelmingly critical discussions of The Importance of Being Earnest focus on the character types and their realization and the putative intention behind the work. An early study by St. John Hankin concludes that 'it is the expression of the author's own temperament and his attitude towards life' (see Bloom 2008: 52), while Russell Jackson considers that in this play, 'Wilde simultaneously engaged with and mocked the forms and rules of Society' (2005: 169); in other words, its business, as Watkin puts it, is to 'criticize or inform' (2010: 134). The text is treated as so committed to everyday realities that there could be no thought of there being underlying mythic patterns to it. For its own part, The Lion and the Jewel has aroused interest on the grounds of the trickster figure and the impotency and vacuity of modernity relative to tradition. But the criticism has tended to dwell on character, with emphasis on satire. According to Jeyifo,

it is a satirical comedy, but the satire is of a gentle, good-natured kind. Most of the satirical barbs are directed at Lakunle, the eccentric schoolteacher, and people like him who propose a superficial, naive, and pretentious view of progress, modernity and Westernization as a counter to what they consider the unmodern backwardness of African village life. Thus, though Lakunle finds his village compatriots insufferably ridiculous in their 'unsophisticated' rural ways, the laugh is on him: we laugh at, and not with him; we laugh at the incongruity between his inflated self-importance and the half-digested, pedantic nature of the 'knowledge' he espouses, and between his affectation of superiority and the utter condescension with which everyone in the village, including even his own pupils, regards his ineptitude and eccentricity (106).

Fariha Ishrat Chowdhury agrees that the play is a "satirical comedy" about the "triumph of tradition over modernity', adding that 'through the plot of The Lion and the Jewel, Soyinka deliberately has put a riddle which gives us a headache on analyzing the victory of Baroka over Lakunle' (2011: 34). He does not explore the riddle beyond the alleged emptiness of modernity. For Kumar, on the other hand, there is no question of satire, rather 'the dramatic environment that Soyinka creates has been enriched with variegated realistic scenes portraying African life very exactly and fashions and characters holding a mirror up to nature and presenting life as it is' (2011: 88).

Criticism of the two plays has been exercised almost exclusively by the textual surface, namely mythos in the sense of an arrangement of incidents with interplay of 'characters, sufferings and actions' (kai êthê kai pathêkai praxeis, Aristotle part I). But Aristotle also indicates that there is a rhythm in this movement of representation (rhuthmôn mimountai), which is not necessarily displayed at the textual surface. The focus of this paper is the shared rhythm that underlies and shapes representation in these dramatic works. Northrop Frye explains as follows:

We saw in our survey of fictional modes that the poet never imitates 'life' in the sense that life becomes anything more than the content of his work. In every mode he imposes the same kind of mythical form on his content, but makes different adaptations of it (Anatomy of Criticism 63).

Aristotle of course focuses on the form which gives identity to the kinds of dramatic works he is chiefly interested in, that is, the tragic form, but he does not lose sight of the pattern which Frye would call the 
'mythical form' as he alludes in Part XIII to the handling of 'traditional materials' and the author's responsibility to preserve 'the framework of the received legends'.

\section{Underlying Currents}

The Importance of Being Earnest and The Lion and the Jewel share related classical norms and dramatic practices. Wilde's play has strong resemblances to Menandrian New Comedy, where,

The characters find themselves in a complicated and unpleasant situation which for a while seems destined to grow steadily worse, but the story is so manipulated that everything works out well in the end and everyone is left happy and contented (O'Neill, xlix).

The Lion and the Jewel, on the other hand, shares features with the Old Comedy associated with Aristophanes, in whose plays,

there is usually a central figure who constructs his (or her) own society in the teeth of strong opposition, driving off one after another all the people who come to prevent or exploit him, and eventually achieving a heroic triumph, complete with mistresses, in which he is sometimes assigned the honors of a reborn god' (Anatomy of Criticism 43).

Baroka is such a central figure constructing his own society in the teeth of strong opposition and driving off those who oppose him. He is not merely a figure standing for tradition but is actively planning to create Ilujinle his village into a sovereign entity, with its own postal service and stamp and other appurtenances of a modern state.

The two plays, however, share a central event strongly looked forward to, drawing their final curtain at the threshold of the event itself. This looked forward to event is marriage. Hereby the plays reflect one of the visions of comedy, namely the establishment and continuation of human community (Frye, 'The Argument of Comedy'). In the sensational marriage of Baroka and Sidi, the vision would be irrational from a Menandrian point of view. But the 'irrational' is also one of the visions of comedy (Gurewitch 1975). Whereas Menandrian comedy concentrates on the overcoming of obstacles to marriage and 'above all on the vicissitudes of youthful passion - the passion, that is, of young men who are blocked by stern fathers, rich rivals, or greedy masters from attaining the women they desire' (Konstan 1995: 93), neither intrigue nor blustery, nor luck is any help to Lakunle in gaining the village belle he professes to be in love with. Thus instead of a community renewing itself by drawing from all available youthful energy, there is a bonding of old and new.

Marriage has deeper connections to the cycle of life itself; and that is the aspect that is of particular importance to this paper. At this level, comedy affords a platform for representation of the vegetation cycle as a pattern of all life. Susanne Langer somewhat echoes this view, where she says that comedy arises wherever and whenever people are gathered to celebrate life, and that the justification of comedy in general is in the fertility rite of the prehistoric people ('Comic Rhythm' 458). She goes on to affirm that the young generation's overthrow of the older generation is both a 'biological truth' and the 'basic rhythm of life' (460), but that such situations cannot always be the 'deeper meaning' in comic sequences, nor should a comic sequence be absolutely reduced to the 'parable of a disguised rite of spring' (460). In Frye, however, the rites of spring are always implicated in comic sequences, specifically the narrative of 'the yearly triumph of spring over winter' ('The Argument of Comedy' 83), life and regeneration over death and dissolution. In literature, therefore, dying may form part of a process looking forward to regeneration as an outcome. As such, it implicates a 'structure of perception' - something to do with the nature of man as animal symbolicum (Martell, Web).Accordingly, what is observed at the horizontal level of connecting together of ideas in a literary work, has function as a 'representative element' (Punter 2007: 2), and is already metaphorical. This is chiefly what gives the literary work resonance, wherever its metaphors may come from, whether the mineral, the cosmic, vegetable or animate spheres of existence.

The plays we are discussing are clearly analyzable in terms of surface and of depth, and we shall follow Northrop Frye's use of the names of the four seasons in the subtropical regions in designating the different myths that run in literature, although one of the plays is of tropical provenance. These are names whose semantic content in mythical terms applies universally. Spring, for instance, is associated with revival and renewal of life in its different forms after the ravage of winter and arid seasons. At the vegetative level, spring ushers in germination of seeds and plant growth; in animal life, the awakening of sexual energy. The story of new life emerging from dry seeds and from fields scorched during the arid season is connected to man's food sources and his survival and is seen under the aspect of hope. Thus is 'mythical fantasy engendered which creates a world of specific representations' (Cassirer 1955: 69). Frye classifies the representations involving the awakening and reactivation of the life cycle as 'the mythos of spring' (Anatomy of Criticism). Courtship and match-making in human society belong here. There follow the winning of the bride and marriage - 'the mythos of summer'. We are not concerned in this paper with the mythoi of autumn and winter which with spring and summer make up the 'mythical form' of representation in art. The mythical forms can stand alone in representation, but they can also connect and attain completion in others. According to Frye, 
Comedy grows out of the same ritual, for in the ritual the tragic story has a comic sequel. Divine men do not die: they die and rise again. The ritual pattern behind the catharsis of comedy is the resurrection that follows the death, the epiphany or manifestation of the risen hero. This is clear enough in Aristophanes, where the hero is treated as a risen God-Man, led in triumph with the divine honors of the Olympic victor, rejuvenated, or hailed as a new Zeus. In New Comedy the new-human body is, as we have seen, both a hero and a social group (1967: 83).

The characters in both The Importance of Being Earnest and The Lion and the Jewel do not readily strike one as 'divine men'. But some of the main ones do pass symbolically from death to new life, which is the underlying pattern in the mythos of spring.

\section{New-Human Body}

Unlike in The Lion and the Jewel where the rites of spring are signaled by the appearance of a youthful, sexually mature female - ripe would be more in line with Baroka's imagery, the chief who ultimately carries off the village beauty - it is first signaled in The Importance of Being Earnest by the manifestation of love between Gwendolen and Jack Worthing. This is immediately associated with a struggle to break out of a semi-darkened world of confused identities into the clear light of knowledge of self and the other. In Soyinka's play, the young female Sidi's attitude towards marriage is to some extent like that of Lady Bracknell in The Importance of Being Earnest, who wishes to ascertain that the material substance of the parties is in favour of her protégés and volunteers that 'When I married Lord Bracknell I had no fortune of any kind. But I never dreamed for a moment of allowing that to stand in my way' (Third Act). Marriage to Lord Bracknell is by calculation and stratagem. Similarly, for Sidi, before she fully comes into her own as the spirit of spring, who she is to marry is connected to who has the financial resources for a bride price. Her answer to Lakunle's passionate profession of love is:

I've told you, and I say it again

I shall marry you today, next week

Or any day you name.

But my bride-price must first be paid.

Aha, now you turn away.

But I tell you, Lakunle, I must have

The full bride-price. Will you make me

A laughing stock? Well, do as you please.

But Sidi will not make herself

A cheap bowl for the village spit (7).

Not only is Lakunle poor and unable to afford a bride-price, but also he is trying to lead a one-man revolution against tradition. On the matter of a bride-price, no impression can be made on tradition without at least one like-minded female who accepts the superior claims of love.

The point, however, is that she herself who awakens desire in others has not been awakened and ushered into the cycle of life and fruitfulness. Lakunle tries by professions of love and fails. Baroka, old and unattractive, whose household gods, despite his many wives 'are starved / For want of child-naming festivities / Since the last two rains went by' (46), through cunning achieves the sexual awakening of the village beauty. Once this is done, Sidi is ready for the service of life:

Kneels down at Sadiku's feet.]

Mother of brides, your blessing ...

SADIKU: [lays her hand on Sidi's head.] I invoke the fertile gods. They will stay with you. May the time come soon when you shall be as round-bellied as a full moon in a low sky (64).

Baroka has overcome his own disadvantages which had rendered him undesirable to Sidi by a secret programme of physical fitness through martial arts and in part by keeping himself well-informed and exercising his mind with new and innovative ideas. He also plays on Sidi's curiousness by getting information out in the public domain that he has become impotent, even submitting to public ridicule for this. In the end, Baroka has completely turned the tables on youth. To Lakunle who ventures to express hope of eventual union when Sidi is mourning her loss of virginity to Baroka, she,

turns round in surprise.

Marry who ... .? You thought...

Did you really think that you, and I . . .

Why, did you think that after him,

I could endure the touch of another man?

I who have felt the strength,

The perpetual youthful zest

Of the panther of the trees?

And would I choose a watered-down, 
A beardless version of unripened man? (63).

The rites of spring in The Lion and the Jewel involve a contest where the fittest alone has access to the mate. It re-enacts the mythic contest between winter and spring, which spring usually wins. Here, however, it is the other way round, so that age conventionally associated with winter here has all the energy of spring and youth. Baroka is really a divine man to accommodate the 'perpetual youthful zest / Of the panther of the trees', whereas Lakunle is 'a watered down, / A beardless version of unripened man'. Baroka has energy to regenerate as a new self, but Lakunle does not pass muster and finishes up on his hams at the base of a tree, shoved down by Sidi, while the procession follows her to her wedding with Broka. He also has magic to awaken the impulses of life and fertility in Sidi, whereas Lakunle is irksome to her and unable to arouse any tender feelings in her. He even tries to put her down by suggesting that she has a smaller brain than him, while she uses against him the bride price he could not afford as a handy weapon of resistance. In our reading, it does not appear to be the case that the reference to a smaller brain is 'Soyinka [presenting] women in a degrading picture' (Muhammad 2011: 322). Similarly, Ahmed has noted that there is no demand upon Baroka to pay Sidi's bride price, nor any reference to his having paid it to be accepted by her as a spouse.

The obstacles to marriage in The Importance of Being Earnest are complex. There is a Menadrian obstacle in the form of Lady Bracknell, a figure with 'double destinations' (Kristeva 43), in so far as she is also the promoter of the love relationship of Algernon and Cecily. For the rites of spring to commence, the obstacle has to be removed, but even more fundamentally, the resolution of the play will depend on the resolution of the double role of Lady Bracknell, both as impeder and promoter of love relationships. Jack Worthing, however, has powerful leverage by way of her nephew Algernon's engagement to Cecily. That young man would probably sink under the weight of his accumulating debts without such an advantageous match; and he has no inhibition exercising that leverage:

JACK. I beg your pardon for interrupting you, Lady Bracknell, but this engagement is quite out of the question. I am Miss Cardew's guardian, and she cannot marry without my consent until she comes of age. That consent I absolutely decline to give.

This is one more complication, therefore; and none can be solved without the others being solved as well.

The Importance of Being Earnest is peculiarly a play of doubles. Jack Worthing, who is Jack in the country and Earnest in town, and while in the country has a brother in town or abroad who is Earnest, although he never has had a brother nor intends to have one, is simultaneously a quester for love and a parental figure and thereby an obstacle to love. Algernon, for his part, the young nephew of Lady Bracknell, who neither has a fortune nor accepts to live as someone without it, will double in the country as the wayward or lost or dead brother Earnest. Miss Prism of course holds the key to the real puzzle underlying the play of confusion and mistaken identity. She is secretly the Winter deity concealed in the bosom of the country house of Worthing/Cardew as governess and instructor in social values and graces. When she is unmasked, all the pieces begin to fall into place. At the same time, she herself is making the transition from winter to spring. The slaying of this Winter deity is purely symbolic:

LADY BRACKNELL: [In a severe, judicial voice.] Prism! [MISS PRISM bows her head in shame.] Come here, Prism! [MISS PRISM approaches in a humble manner.] Prism! Where is that baby? [General consternation. The CANON starts back in horror. ALGERNON and JACK pretend to be anxious to shield CECILY and GWENDOLEN from hearing the details of a terrible public scandal.] Twenty-eight years ago, Prism, you left Lord Bracknell's house, Number 104, Upper Grosvenor Street, in charge of a perambulator that contained a baby of the male sex. You never returned. A few weeks later, through the elaborate investigations of the Metropolitan police, the perambulator was discovered at midnight, standing by itself in a remote corner of Bayswater. It contained the manuscript of a threevolume novel of more than usually revolting sentimentality. [MISS PRISM starts in involuntaryindignation.] But the baby was not there! [Every one looks at MISS PRISM.] Prism! Where is that baby? [A pause.] (Third Act).

Miss Prism's emergence from her hidden life is first of all a resurrection to shame, but she purges herself of her Winter identity by her open and unreserved confession. Henceforth she can participate in the rites of spring to the extent that she is almost mistaken for a mother. But the true mother is Lady Bracknell, and as a member of the 'society of the senex' (Anatomy of Criticism 171) to which Dr Chasuble also belongs, one of her major functions in this sequence is the assigning of identities. It is Jack Worthing that is most in need of one. He explains the situation to Lady Bracknell:

I am afraid I really don't know. The fact is, Lady Bracknell, I said I had lost my parents. It would be nearer the truth to say that my parents seem to have lost me... I don't actually know who I am by birth. I was... well, I was found.

LADY BRACKNELL. Found! 
JACK. The late Mr. Thomas Cardew, an old gentleman of a very charitable and kindly disposition, found me, and gave me the name of Worthing, because he happened to have a first-class ticket for Worthing in his pocket at the time. Worthing is a place in Sussex. It is a seaside resort.

LADY BRACKNELL. Where did the charitable gentleman who had a first-class ticket for this seaside resort find you? (First Act)

In pursuing the lovers from the city to the country, Lady Bracknell functions as 'the senex iratus or heavy father' (Anatomy of Criticism 171-172) of conventional Menandrian comedy. But then the young man she would prevent bursts like a shoot from a hidden life as Jack Worthing into a new life as Earnest Moncrieff, becoming acceptable to her as a son-in-law. Accordingly, that Lady's previous objection turns out not to be a manoeuvre by the society of the senex to impose the law and spoil the happiness of the young but to protect what is in her materialistic view the best interest of her only daughter who, according to her, was going 'to marry into a cloak-room, and form an alliance with a parcel' (First Act).

In the circle of life that emerges from the action of The Importance of Being Earnest no one is left out. It is a happy group and a harmonious body that emerges, which is quite different from the outcome in The Lion and the Jewel. Here Baroka is apparently the figure of senex iratus. But he does not engage Lakunle, nor overtly pressure Sidi against marrying Lakunle. Sidi's decision on the matter is known already in the opening scene. And it is her decision. Therefore the struggle of the play is not between the two men. In the opening scene, Lakunle blusters about him as someone he wishes to take on because of his moral character which he finds objectionable, not for anything directly to do with Sidi:

LAKUNLE: ... For now, it is this village I shall turn

Inside out. Beginning with that crafty rogue,

Your past master of self-indulgence -Baroka.

SIDI: Are you still on about the Bale?

What has he done to you?

The struggle of the play is between Sidi and Lakunle; and if Sidi is the spirit of spring and fruitfulness, Lakunle is the spirit of winter and aridity. Hence his discourse is full of prescriptions and impositions. In the end, he is the one to be shoved aside and left behind that the marriage may proceed. This treatment of Lakunleis brutal, but it is familiar in the Old Comedy of Aristophanes, as in The Clouds and The Acharnians.

Sidi is looking to fruitfulness and renewal of the world of Ilujinle: she is the very spirit of spring and Lakunle is without a place in that world. He is the stranger whose attention and interest is how to get out of this world into that of Lagos and Ibadan:

Together we shall ... eat,

Not with fingers, but with knives

And forks, and breakable plates

Like civilized beings....

I want to walk beside you in the street,

Side by side and arm in arm

Just like the Lagos couples I have seen

High-heeled shoes for the lady, red paint

On her lips. And her hair is stretched

Like a magazine photo. I will teach you

The waltz and we'll both learn the foxtrot

And we'll spend the week-end in night-clubs at Ibadan.

Oh I must show you the grandeur of towns

We'll live there if you like or merely pay visits.

So choose. (8-9)

This reflects the blustering manner affected by Lakunlein this play. But it is only talk and quite incapable of giving rise to a firm intention. When the play ends, he is not only still in this place where he believes that he does not belong, but also his attitude is that of one abandoned in a dump, while the living community moves on.

Given the vital force signified by Sidi, leaving Ilujinle would be the death of that community. She is not attracted by the prospect of high-heeled shoes and painted lips which are put out to her as a bait. She scorns both the bait and Lakunle, who is consigned to another world altogether - the one that figures in his imagination as the place to be. Hence in the mime of the encounter of cultures between Ilujinle and the outside world, which for Ahmed is 'the major point of argument' in this play (Web.), Sidi substitutes him for the stranger from the outside world and prevails upon him to play the stranger's part. This is one of the opposing and exploitative forces Baroka would drive off in his effort to found and maintain his own society:

You are dressed like him

You look like him

You speak his tongue 
You think like him

You're just as clumsy

In your Lagos ways -

You'll do for him! (14).

Sidi is undoubtedly the 'new-human body' in this play, both heroine and social group, a divine female, since the sun is her lover $(11,51)$. She moves from an object of interest at the outset to the mover of events at the end, while remaining at the centre of events. The vigour of this new body is felt by Lakunle in the scene where he is cast out; at the same time she reveals to him the source of this vigour:

Out of my way, book-nourished shrimp

Do you see what strength he has given me?

That was not bad. For a man of sixty,

It was the secret of God's own drought....

But you, at sixty, you'll be ten years dead

In fact, you will not survive your honeymoon (64).

Lakunle's pretensions of Western outfit and advanced ideas are unmasked by Sidi. He does not inspire any kind of confidence, whether in himself or in a future in which he is involved, especially where he would be a leader. Rather it is Sidi that promises stability and continuity in the community. As Sadiku says,

Do you know what it is to be the Bale's last wife? I'll tell you. When he dies - and that should not be long; even the Lion has to die sometime - well, when he does, it means that you will have the honour of being the senior wife of the new Bale (20).

She is a centre of stability in the dynastic succession and ensures that the desiccation and emptiness associated with Lakunle is kept at bay.

\section{Conclusion}

The 'textual existents' (Seymour Chatman 1980), which are encountered immediately in reading fictional works tend to hold and sustain reading attention. But readers also usually treat them as not existing for themselves and for their own sakes. Critical reading therefore goes with analysis and interpretation, in search of deeper patterns and meanings. With respect to Wilde's The Importance of Being Earnest and Soyinka's The Lion and the Jewel, what has usually guided interpretation is the intention of the playwright. With respect to The Lion and the Jewel, there have also been concerns about the handling of Yoruba cultural materials. The comparative reading of these texts undertaken in this study has led us to ask questions which are beyond cultural affiliations and individual intentions. Making reference to Northrop Frye's account of drama, both tragedy and comedy, as deriving from the same common source, ritual and the mythic insights which the ritual commemorates, we have been able to establish links to shared features respecting the genus of comedy and the archetypal meanings that it enacts. Comedy involves perception under the aspect of hope: hope in the triumph of life over death. It would normally involve a struggle, but since life is associated with fragility, there is always something magical or irrational (marvelous) in its victory. But the fundamental business of a comedy is the narrative or dramatic enactment of this overcoming of the threat of death. And that is what gives meaning to the configurations of the textual existents in each work. The Lion and the Jewel goes the way of Old Comedy in this enactment; The Importance of Being Earnest the way of the New Comedy.

\section{Works Cited}

[1]. Ahmed, Ashraf. 'Social Picture in Wole Soyinka's The Lion and the Jewel'. Retrieved from, https://www.academia.edu/4752792/Social_Picture_in_Wole_Soyinkas_The_Lion_and_the_Jewel. Web.

[2]. Aristotle, Poetics. Trans. A.S. Butcher. Orange Street Press http://www.keystonenet.com/ jesch/osp/ sparks@eserver.org.1998. PDF.

[3]. Aristotle. PeriPoiêtikês. Retrieved from, http://www.perseus.tufts.edu/cgi-bin/ ptext?lookup=Aristot.+Poet. $+1462 b$. Web

[4]. Bloom, Harold. Oscar Wilde. New York: Infobase Publishing, 2008. PDF.

[5]. Cassirer, Ernst. The Philosophy of Symbolic Forms. Trans. Ralph Manheim. Vol. 2. New Haven: Yale University Press, 1955. PDF.

[6]. Chatman, Seymour. Story and Discourse: Narrative Structure in Fiction and Film. Ithaca: Cornell University Press, 1980. PDF.

[7]. Chowdhury, FarihaIshrat. 'Sidi's Choice of Baroka and the Victory of Traditional Values over Western Ones in Wole Soyinka's The Lion and the Jewel'. Language in India: Strength for Today and Bright Hope for Tomorrow. 11. 6 (2011): 28-35. PDF.

[8]. Frye, Northrop. 'The Argument of Comedy.' Shakespeare: Modern Essays in Criticism. Ed. Leonard F. Dean. Oxford: Oxford UP, 1967. 79-89. Print.

[9]. Frye, Northrop. Anatomy of Criticism. New York: Atheneum, 1970.Print.

[10]. Gurewitch, Morton. Comedy: The Irrational Vision. Ithaca: Cornell University Press, 1975. Print.

[11]. Jackson, Russell. 'The Importance of Being Earnest'. Cambridge Companion to Oscar Wilde. Ed. Peter Raby Cambridge: Cambridge University Press, 2005, 161-177. PDF.

[12]. Jeyifo, Biodun. Wole Soyinka: Politics, Poetics and Postcolonialism. Cambridge: Cambridge University Press, 2004. PDF

[13]. Konstan, David. Greek Comedy and Ideology. New York: Oxford University Press, 1995. PDF.

[14]. Kristeva, Julia. Desire in Language: A Semiotic Approach to Literature and Art. Trans. Thomas Gora, Alice Jardine, and Leon S. Roudiez. Oxford: Blackwell, 1980. Print. 
[15]. Kumar, K. Naveen. Yoruba Tradition and Culture in Wole Soyinka's "The Lion and the Jewel". Researcher's World: Journal of Arts, Science and Commerce. II.3 (2011): 88-97. PDF.

[16]. Langer, Susanne. 'The Comic Rhythm'. Eight Great Comedies. (Eds.) Sylvan Bernet, Morton Berman, and William Burto. Canada: Penguin, 1985, 456 - 460, Print.

[17]. Martell, Timothy James. 'The Structure of Perception: Ernst Cassirer's Phenomenology of Vision'. <https://www.academia.edu/5196495/The_Structure_of_Perception_Ernst_Cassirers_Phenomenology_of_Vision> Retrieved 12/12/2013. PDF.

[18]. Muhammad, Usman Ambu. 'Wole Soyinka's The Lion and the Jewel: A Distortion of Female Image'. JORIND 9.1 (2011): $320-$ 323. <www.transcampus.org/journals. www.ajol.info/journals/jorind> PDF.

[19]. O'Neill, Eugene. Jr. 'General Introduction: Comedy'. The Complete Greek Drama. (Ed.) Whitney J. Oates and Eugene O'Neill, Jr. New York: Random House, 1938. PDF.

[20]. Punter, David. Metaphor: The New Critical Idiom. USA: Routledge, 2007, Web.

[21]. Soyinka, Wole. The Lion and the Jewel. London: Oxford University Press, 1963.

[22]. Watkin, Amy. How to Write About Oscar Wilde. New York: Infobase Publishing, 2010. PDF. 